\title{
Illegal, Not Wanted, Unnamed: Woody Guthrie's Exploration of Media, Immigration, and Identity in "Plane Wreck At Los Gatos (Deportee)"
}

\author{
Edward A. Shannon ${ }^{1}$
}

Woody Guthrie's 1948 song "Plane Wreck At Los Gatos (Deportee)" demonstrates Guthrie's talents not only as a songwriter, cultural worker, activist, but also as documentarian, journalist, and media critic. The song describes a plane crash that took the lives of 28 unnamed Bracero workers being deported to Mexico in January 1948. More, the song's grammatical, linguistic, and syntactical sophistication encourages listeners to consider not just the tragedy of the crash, but also the conditions of workers, and the politics of media coverage of the "others" serving the US agricultural system. Beyond those specific political concerns, the song also preserved the memory of the victims of the titular plane crash, leading to the rediscovery of their names after 60 years. This reading of the song contextualizes Guthrie as a critic of mass media as well as a laborer in that field. The song is informed by Guthrie's work as a journalist and novelist as well as his time as a songwriter, recording artist, and performer. "Deportee" reflects Guthrie's understanding of and resistance to mass media's power to obfuscate as well as communicate. [Article copies available for a fee from The Transformative Studies Institute. E-mail address: journal@transformativestudies.org Website: http://www.transformativestudies.org (02020 by The Transformative Studies Institute. All rights reserved.]

KEYWORDS: Woody Guthrie, Tim Z. Hernandez, Los Gatos, Deportee, Bracero, Folksong, Migrant Workers.

In August 2014, while I was working on an early draft of this essay ${ }^{2}$, the phone rang. The call was a political solicitation — and as it turned out, an

\footnotetext{
${ }^{1}$ Edward A. Shannon is Professor of Literature (and former convener of the Literature major) at Ramapo College of New Jersey, USA. He teaches courses in American literature, American Studies, general humanities, and graphic novels. He was named a 2005 Woody Guthrie Fellow by the Woody Guthrie Foundation. He also writes about Mark Twain, and has been awarded a Mark Twain Quarry Farm Fellowship in Summer 2020. He has also published on cartoonists Robert Crumb, Art Spiegelman, George Herriman, and Winsor McCay.
} 
uncanny one: familiar and fantastical. A recorded voice identified the caller as representing a conservative coalition and asked me to hold for another recorded voice, that of Newt Gingrich. These Gingrich robocalls had been coming for months; usually, I just hung up. This time, out of curiosity, fatigue, and political masochism, I listened. Gingrich alerted me to the threat immigration held for the nation: then-President Obama was endangering the U.S. by flying in criminals from Honduras. Gingrich reminded me of Governor Rick Perry's warning that terrorists from Iraq and Afghanistan were flocking to Mexico to cross into Texas. Things looked dire.

The call had come just as I was wrestling with Woody Guthrie's 1948 song "Plane Wreck At Los Gatos (Deportee)," ${ }^{3}$ in which Guthrie responds to media reports of a plane crash that killed twenty-eight farm workers in the "US-Mexico [Bracero] guest worker [program] that brought millions of Mexicans to the United States to work in agriculture and help construct railroads" (Chávez 21). At the time of the call, I was reading these lines:

My father's own father, he waded that river,

They took all the money he made in his life;

My brothers and sisters come working the fruit trees,

And they rode the truck till they took down and died. (lines 9-12)

Sometimes, academic pursuits seem academic in the worst sense of the word, serving only to fill the air with intellectual argument. To paraphrase Woody Guthrie's comments on pop music, in those moments, our work can seem "No good to nobody. No good for nothing" (Guthrie, "WNEW" 223). That phone call, though, offered a sign that Guthrie's writing was still doing its good work. The recording instructed listeners who wanted to talk to an operator and donate to the cause to push "one." Those who wanted to stop getting calls needed to do more than just push a button, though. For that, you needed to jot down an 800 number and make another call. In a breach of protocol (I had no intention of donating), I pushed "one" and had a conversation with the operator, sharing with her not only my personal political views, but also the odd

\footnotetext{
2 This essay was first composed in 2014. Since that time, much work has been done on "Deportees," by Kannan, Hernandez, and others. This draft reflects that more recent work.

${ }^{3}$ Woody Guthrie is the author of "Deportee." Martin Hoffman composed the music. See Kannan, "Rhetorics."
} 
coincidence about my current writing task and the Woody Guthrie lyrics on my screen. She happily removed my number from their lists.

The robocall is a new form of political media that Woody Guthrie, archetypal American folksinger / songwriter and composer of "This Land is Your Land" could not have foreseen. Had he learned about robocalls, though, he might have been intrigued. Despite his popular image, Guthrie was more a creature of mass media than a homespun voice of unlettered tradition. His own political agenda demanded access to a mass audience, one he pursued through radio, recorded music, journalism, visual art, film scores, theater, dance, children's records, textbooks, live performances: whatever worked. During his relatively short career, he DJ'ed on the radio, hung around movie sets, laid down tracks in many a recording studio, wrote for the Daily Worker, People's World, and New York Times, collected folk songs and edited songbooks, drew political cartoons, and published an autobiographical novel with a major publisher. In all these pursuits, Guthrie presented himself as just another Dust Bowl refugee. Matthew Blake writes that Guthrie's goal as a newspaper columnist was to become "an advocate for similarly dispossessed migrants" (187), but Blake could have said the same about all of Guthrie's work.

His relationship with media was - and still is-tangled. For a longdead, hardscrabble outsider, he has a robust web presence and is well represented on iTunes, in whatever CD bins remain, and (because what's old is new again) on newly-pressed 180 gram vinyl: songs written by Woody Guthrie, performed by Woody Guthrie, songs about Woody Guthrie, songs called "Woody Guthrie." There are eBooks, audiobooks, and podcasts. Guthrie's posthumous media presence is by no means anomalous. The half century and more since the end of his career in the 1950's and subsequent 1967 death have seen the discovery of not only two unpublished novels, but dozens and dozens of songs Guthrie wrote but never recorded or composed tunes for, leaving that to contemporary musicians performing everything from punk to folk to klezmer to jazz. Few of these songs are as haunting as 1948's "Deportee," Guthrie's "compassionate paean to deported . . . Mexican workers" (Kanstroom 46), chronicling those twenty-eight workers' deaths. But Guthrie's real subject is not so much the tragic accident as the workers' treatment in the U.S. while they lived and - even more so - their dismissal by the media in death. While living, the workers were used by U.S. famers, who only "[fly] 'em back to the Mexican border / To pay all their money to wade back again" (Guthrie, Hard Travelin' 44). After they died, they were erased: "The radio says, 'They are just deportees"' (Guthrie, Hard 
Travelin' 44). As a musician and journalist, Guthrie knew media's power to communicate as well as obfuscate, so it is not surprising one of his most significant songs resists media labels so powerfully.

"Deportee" was not only timely but also prescient. It still strikes a nerve when Guthrie speaks in the voices of these Bracero workers: "Some of us are illegal, and some are not wanted" (line 13). To illustrate Guthrie's insight and foresight here, even today, there is pushback against the song. One need only do a quick web search on the Los Gatos crash; mention of the crash (and almost always Guthrie's song) appears in a variety of contexts: web sites devoted to aviation accidents, California history, folk music, and agriculture.

Three Rocks Research, a non-profit supporting California culture and history complains that Guthrie uses the term "deportee" too loosely and that "Guthrie had [a] mistaken understanding of the bracero program." Correcting the folk singer, the site notes that the Bracero program:

permitted Mexican farm laborers into the United States [and that] [the] agreement . . . required the United States to guarantee transportation and repatriation of all Mexicans entering the United States under this program ... Being a 'Deportee' in this fashion was simply the U.S. government meeting their obligation under the treaty and in no way affected the labor status of the bracero. ("DC3 Aircraft Crash")

The truth is, though, that Guthrie has his facts, terminology, and his argument right. Guthrie does not say the workers are "deportees." He writes, "The radio says, 'They are just deportees"' (emphasis mine; line 24). And "deportee" is precisely the word used in news accounts. The New York Times reported-in a story that Guthrie, a lifetime news junkie then living in New York, certainly read - that the plane held "twentyeight Mexican deportees" ("32 Killed").

Guthrie offers a further qualifier. He writes in the voice of the workers, "Some of us are illegal, and some are not wanted" (line 13). Legality is not all of what Guthrie is about here; "not wanted" speaks not just to legislation, but to moving human beings around like discarded farm tools. These workers were caught in a period of intensified confusion over their social and legal standing, reflected in later quibbling about Guthrie's use of the term "deportee." After the end of the war, the U.S. had begun to lose its taste for immigrant labor, and "by the fall of 1947 . . . soldiers began trickling home" (Hernandez, All They 33). The soldiers were not the only returning American workers: Japanese- 


\section{Edward A. Shannon}

American "internment camps had only recently closed" and "thousands of Japanese Americans were being bused and trained" for new lives, making "Mexican labor . . . once again dispensable" (Hernandez All They 33). Guthrie's song recognizes that the same was true about the Mexican laborers themselves.

The plane crashed on January 28, 1948. But "in late 1947 . . the program [had been] temporarily discontinued" leading to "massive illegal immigration countered by various arrangements with employers and an ad hoc 'legalization' program designed primarily to meet the needs of large agricultural employers" (Kanstroom 220). At this time, "each bracero worker entered into a contract directly with a U.S. employer. The U.S. government was no longer a signatory to the individual work contract" (Kanstroom $n$. 323). These workers faced uncertainty as to their legal status at every turn; it seems certain that they must have felt like deportees as they were escorted onto that plane.

The power of Guthrie's lyric is its empathy and simplicity as the song wrestles with the word "deportee." We need to name "these friends, all scattered like dry leaves" (line 23), rather than "chase [them] like outlaws, . . . rustlers, [or] thieves" (line 16) simply because their "work contract's out" (line 14). More to the point, in imagining names for these unnamed workers, Guthrie demonstrates that even while he enters the nadir of his career, his powers of invention are yet formidable. In 1956, he will be committed to Greystone Park State Hospital in Morris Plains, N.J., misdiagnosed as a "[s]chizophrenic" (Cray 377). The rest of his life would be largely lived in hospitals, and "by the time [of] the 'worst plane crash in California history' . . Huntington's [Disease] had taken the better part of his musical ability" (Hernandez, All They 193). Regardless, in this "last great song" (Klein 362) his act of naming reminds readers and listeners of the extent of Guthrie's abilities. He both shouts into the media's silence and practices a kind of rhetorical silence himself:

Although Guthrie assigned names to the Mexican passengers, he did not name the four American crew members. By assigning names only to the Mexican passengers, he draws attention to the silence surrounding their names and links it to the exploitative labor conditions that he sets forth in the other song lyrics. (Kannan, "Rhetorics" 88-89)

Not only does Guthrie "not name the four American crew members" (89). He does not even mention the crew, as though the plane flew itself. 
Reversing the priorities of the media, he focuses on the nameless and ignored.

Inverting the naming and silencing practices of the privileged, evoking powerful emotions of loss and redemption, "Deportee" demonstrates Guthrie's sophistication as a songwriter, cultural worker, and activist. It also reveals his ability as a documentarian, journalist, and media critic. Finally and most powerfully, the song's central concern about human dignity still rings not only true for its day but as an apt commentary in the $21^{\text {st }}$ century, when terms like "illegal" and "deportee" dominate headlines just as they did while Guthrie lived. The violence of xenophobic rhetoric has only escalated since the Gingrich robocall. "Illegal" and "deportee" are almost friendly compared to the broad accusations leveled by the President, who has "paint[ed] Mexico as a nation of rapists, drug smugglers and trade hustlers who [should] pay for [a] 2,000-mile border wall" (Editorial Board np) to contain themselves.

Thinking about "Deportee" means thinking about the plane crash and its press coverage, as well as the song's place in Guthrie's output and its rediscovery in the late 1950 's. Guthrie does not exaggerate either the horror of the accident or how media minimized the workers' deaths. The January 29, 1948 New York Times article relates that the plane apparently "'explode[d] and a wing fell off' before it plummeted to the ground. A number of those in the plane appeared to jump or fall before the aircraft hit the earth" ("32 Killed"). The Times reports the plane held "twentyeight Mexican deportees" and a crew: "Frank Atkinson . . . Mrs. Bobbie Atkinson, his wife, stewardess . . . Marion Ewing of Balboa, copilot . . . and [a] guard ... Frank E. Chaffin" ("32 Killed"). The word "deportee" surely echoed in Guthrie's mind with "refugee," a term he had reclaimed and adopted during the Dust Bowl more than a decade earlier, most famously in his 1935 song "Dust Bowl Refugee." In 1948, dissatisfied with reports like the above, Guthrie takes it upon himself to name the dead at Los Gatos: "Goodbye to my Juan, goodbye, Rosalita, / Adiós mis amigos, Jesus y María" (lines 5-6). Naming was important to Guthrie in both humane and political contexts. The story of the Los Gatos crash was not the first to motivate Guthrie to correct or augment a news story about such a tragedy.

In 1940, with Millard Lampell, Lee Hays, and Pete Seeger, Guthrie formed The Almanac Singers, so named because "most American families owned two books: The Bible and The Farmer's Almanac. The Bible was a guide to the next life and the Almanac to this one" (Klein 191). The group aimed to become an almanac of practical information and frequently turned to the news for inspiration. Guthrie's 1942 "The 


\section{Edward A. Shannon}

Sinking of the Reuben James," like "Deportee," responded to newspaper accounts of tragic loss of life, in this case, following the destruction of a military destroyer on October 31, 1941:

While escorting convoy HX-156, the American destroyer U.S.S. Reuben James was torpedoed and sunk with the loss of 115 of 160 crewmen, including all officers. Although not the first U.S. Navy ship torpedoed before the war, the Reuben James was the first one lost. ("A People at War" np)

This song also sought to rescue from obscurity working people whose names might be forgotten. Guthrie "decided the best way to humanize the tragedy would be to name all 86 victims" (Klein 216). The result was an unwieldy, unsingable list:

Dennis Howard Daniel, Glen Jones and Howard Vore Hartwell Byrd and Raymond Cook, Ed Musselwhite and more Remember Leonard Keever, Gene Evans and Donald Kapp Who gave their all to fight [aboard] this famous fighting ship. (quoted in Klein 216)

Seeger and the Almanacs convinced him to settle on a plea for communal memory of the lost seamen: "What were their names, tell me, what were their names? / Did you have a friend on the good Reuben James?" (Guthrie lines 7-8).

"Deportee" and "Reuben James" are just two songs where Guthrie demonstrates the power of naming. Vani Kannan points to "I Just Want to Sing Your Name" (Kannan, "Memorializing 'Deportees"' 89), a song Guthrie composed for Ballads of Sacco \& Vanzetti in 1947, the year before he wrote "Deportee." As in "Reuben James," Guthrie repeats the names of Bart Vanzetti, Nicola Sacco, and their family members as well as Judge Webster Thayer, who presided over their trial. Guthrie pointedly observes about Thayer, "I don't want to sing your name" (Guthrie, Lyrics). By the time he writes "Deportee" the following year, he not only omits the names of the crew, he remains silent about the omission.

A patriotic wartime call to arms, "The Sinking of the Reuben James," benefits from Guthrie's choice not to list those names. Unlike the story that inspired "Deportee," of course, 1941 press accounts had dutifully listed the names of the American servicemen who died on the Reuben James. Those news reports were Guthrie's source for his catalog of the 
dead. Thus, "Deportee" is a more powerful and powerfully pointed song where Guthrie grapples with the loss of identity and dignity workers suffer when consigned to new categories of disenfranchisement by media, government, or industry. Guthrie's use of "deportee" still resonates with the debates over the shifting use of terms like "illegal immigrant," "refugee" (after Katrina in 2005), and-of course"deportee."

Guthrie routinely referred to himself and other Okies as "refugees" in his songs, newspaper columns, and elsewhere. He seldom deploys the term without reservation, as he equated "deportees" from European fascism to those fleeing the American variety:

those same fascists - and the free market behind them - . . had turned Guthrie's 'people' into refugees, a term, it seemed to Guthrie, equally applicable in California, Hitler's Germany, and Franco's Spain ... (Kaufman 24)

Nancy Isenberg notes that during the Dust Bowl, "'Okies and 'Arkies' captured the media" (Isenberg 213), and "refugee" was just one of the many disparaging names forced on those "dislodged humans [driven] down the road 'like particles of dust"' (213). While "migrant workers called themselves 'Migs,' . . . others labeled them 'rubber tramps,' or 'shantytowns on wheels'" (213). The labeling of poor workers had real repercussions. In 1927, the U.S. Supreme Court's "revolutionary decision in Buck v. Bell . . gave the state the power to regulate the breeding of its citizens" (Isenberg 200). Guthrie may have shouldered "refugee" with grudging pride, but then as now, these labels have their price: "by 1939 . . . California-based eugenicists had been targeting the migrants, arguing seriously for 'Okie' sterilization, voluntary or otherwise" (Kaufman 24).

"Deportee," the song that most powerfully speaks to Guthrie's discomfort with alienating media labels, has an odd biography. The song outlived its author and its subjects in strangely transformative fashion. The lyrics for "Deportee" were discovered and the tune composed by "Martin Hoffman, a Colorado State University undergraduate English major, folk musician, and soon-to-be-teacher . . . [in] 1957" (Kannan, "Rhetorics" 2). Hoffman later introduced the song to Pete Seeger (Kannan, "Rhetorics" 2), and it had its first success as a recording in the early 1960's, while Guthrie lay dying and voiceless in a Brooklyn hospital. Since then, the song has been recorded and performed by an array of figures, including Dolly Parton, Bruce Springsteen, Bob Dylan, the Kingston Trio, Johnny Cash, The Byrds, and KT Tunstall, to name 


\section{Edward A. Shannon}

just a few. While it is not unusual to find so many varied artists covering a Guthrie song, "Deportee" is one of the few songs Guthrie never sang himself to have garnered so much attention. A somber power haunts Guthrie's lyrics, infused with a subtle and unique grammatical urgency that reinforces, complicates, and builds upon his thematic concerns. Guthrie opens the song in the middle of his story, perhaps confusing some listeners with a scene that has the air of an ending:

The crops are all in and the peaches are rott'ning,

The oranges piled in their creosote dumps (lines 1-2).

The first line curiously confronts us with death and decay, images out of step with the end of the harvest season. After "The crops are all in," Guthrie fans might expect a celebration of life. the world abounds in harvest songs and festivals, but this harvest ends with the contradictory image of "peaches ... rott'ning" and "oranges piled in . . . creosote dumps" (lines 1-2). As the song progresses, we find that this harvest song is about death and loss, not life and birth. This is a song of borders in more ways than one.

Guthrie refers to the use of creosote to make excess fruit inedible. He calmly tosses off this line, not stopping to linger on the injustice of an agricultural system that keeps workers poor and hungry while destroying "excess" food. Like a journalist (or an almanac), Guthrie simply reports the facts. But his silence here offers an unspoken, implied compliant not just about our treatment of the human beings who collect our harvest but our treatment of the harvest itself. ${ }^{4}$ In a 1947 autobiographical sketch, Guthrie writes dismissively of:

the false front decay and rot of California's fascistic oil and gas deals, the ptomaine poison and brass knucks [sic] in the jails and prisons, the dumped oranges and peaches and grapes and cherries rotting and running down into little streams of creosote poisoned juices. (Guthrie, "My Life" 4)

For Guthrie, such agricultural practices are on a continuum of political oppression and violence. Elsewhere in "Deportee," he returns to the image of rotting vegetation, in a metaphorical context, when he asks: "Who are all these friends, all scattered like dry leaves?" (line 23).

\footnotetext{
${ }^{4}$ In "Christ for President," (another song Guthrie left for others to complete), Guthrie echoes this sentiment: "Every year we waste enough / To feed the ones who starve / We build our civilization up / And we shoot it down with wars" (Guthrie, "Christ" np).
} 
Woody Guthrie is one of the few songwriters of his or any era willing and able to write songs that incorporate the real language of working people and still produce songs of stunning power. Despite (or maybe because) he uses words like "creosote," he crafts profoundly emotional songs. In his 1941 "Grand Coulee Dam," Guthrie describes the river as the site where productive "factories hum, / Making chrome and making manganese and light aluminum" (Guthrie, "Grand Coulee Dam" lines 1718). Not the sort of language you hear from Irving Berlin.

The next two lines address an unambiguous, literal boundary: "They're flying 'em back to the Mexican border / To pay all their money to wade back again" (lines 3-4). By simply recounting the truth, Guthrie bumps up against a subtler border: that between subject and antecedent. The line that introduces the real subjects of the song is confusing: "they" are flying "[them]" back? Who are "they" and who is "[them]" (lines 1-2)? Of course, the song bows to the syntax of power: powerless workers are deported by the powerful. The California fruit growers, the U.S. government, and the owners fly the laborers back. We do not need to be told-the weak are moved about at the convenience the strong. Intriguingly, Guthrie does not identify himself with the "American" or with his government. The song reads, "They're flying 'em back to the Mexican border"; not "We're flying 'em back" (emphasis mine; line 3). ${ }^{5}$

Compounding Guthrie's grammatical ambiguity is the connection between the "theys" of this line to the plural nouns "oranges" and "dumps." No reader or listener seriously thinks the song implies that "creosote dumps" are flying anyone anywhere, but there is certainly a breakdown in syntactic expectations. Guthrie has exploited this kind of grammatical discomfort before. In 1941's "Pastures of Plenty," Guthrie's narrator, a displaced migrant from Oklahoma making his way north by working west coast fields, sings:

California, Arizona, I harvest your crops

Well it's North up to Oregon to gather your hops

Dig the beets from your ground, cut the grapes from your vine

To set on your table your light sparkling wine ("Pastures" lines 9-

12)

\footnotetext{
${ }^{5}$ Tracing Guthrie's lyrics usually means encountering multiple versions of the same song. For instance, "[Lance] Canales [visited] the Woody Guthrie Archives in Tulsa, Oklahoma, and [found] another version of ["Deportee"] written in the first person, as if the event had happened to Guthrie himself ('My crops are all in and my peaches are rotting')" (Kannan, "Memorializing 'Deportees"' 90).
} 


\section{Edward A. Shannon}

The "I" of the first line is immediately displaced by "your." In these four lines, the possessive pronoun "your" is repeated five times, comprising one seventh of the stanza's thirty-seven words. "You" and "your" appear another eleven times throughout the song. This worker has no illusions about his or her place at the table. Guthrie uses mismatched pronouns to indicate alienation, a distinct shift from the more hopeful sentiments he articulated just years before in his most famous composition, "This Land is Your Land," a song of expansive invitation:

This land is your land

This land is my land

This land was made for you and me ("This Land" lines 1-4).

Guthrie efficiently communicates both community and isolation with a well-chosen pronoun. When he turns in 1948 to comment on newspaper accounts of the plane crash at Los Gatos, his problematizing "us" and "them" is either intentional or instinctual.

Naming is the heart of this short song chronicling not just the workers' deaths, but the denial of their humanity by media reports assigning them only mass identity: "The radio says, 'They are just deportees'" (line 24). Guthrie will have none of it. While his first stanza stirs images of death and explores the ambiguities of language with his use of "them" and "they," his chorus powerfully personalizes the crash victims, giving them names and offering simple farewells by way of eulogy:

Goodbye to my Juan, goodbye, Rosalita,

Adiós mis amigos, Jesus y María. (lines 5-6)

He begins with common Spanish names "Juan" and "Rosalita," innocently choosing seemingly random names for the willfully forgotten. But the second line of the chorus more aggressively shifts from English to Spanish, and chooses the less than random "Jesus y María," invoking the Holy Family, naming but also sanctifying the dead. Guthrie follows his invocation of the sacred by shifting to child-like innocence, "You won't have your names when you ride the big airplane" (emphasis mine; lines 7). "Pastures of Plenty" shares a similarly innocent lyric. Is Guthrie's use of "your" an intentional dig at the owners who exclude those who create their wealth? Or are solicitous lines like "[we] set on your table your light sparkling wine" (emphasis mine; "Pastures" line 12) 
simply an instance of the songwriter using vernacular? The listener / reader must decide.

A humble tone pervades "Deportee." Guthrie is dismayed, disappointed, and angry. But the song is not bitter, acrimonious, or hostile. If anything, the speaker reels from the punch of the tragic news, and goes searching through a past not necessarily his own. Crossing borders of time, family, nation, and ethnic identity, the speaker goes from hearing about the migrants to becoming one of them-or perhaps a relative or co-worker who has been spared this latest tragedy. He sings, "My father's own father, he waded that river, / They took all the money he made in his life" (lines 9-10). These lines are not autobiographical. Guthrie's grandfather did not "[wade] that river"; he was a "Scottish and Irish" Texan whose family had actually made a reputation "around the Big Bend of the Rio Grande . . . chasing off . . Mexicans who'd come across the river hoping to make off with the Guthrie stock" (Klein 2). But, never mind, for purposes of this song, Guthrie's speaker is the child of Mexican migrants, victims of a system that bleeds the poorest workers of "all the money [they make] in [their lives]" (Guthrie, "Deportee," line 10). Like his "brothers and sisters," he came to "[work] the fruit trees" (line 11). Sadly, though, the speaker adds the odd note that his "brothers and sisters . . . . . . rode the truck till they took down and died" (lines 11-12). This cryptic reference to "the truck" is never explained. Is this the truck that brought the Bracero workers to the airstrip? That brought them to "come [work] the fruit trees"? It doesn't really matter. To ride this truck, to be transported like farm tools, is to lose control of your destiny, to "take down and [die]" (line 12).

Loss of self-determination echoes through the decades as one of the controlling themes of the song, as does Guthrie's empathy for those facing challenges not his own. The shifting narrator now speaks not as a worker testifying to the tragedy of others, but perhaps as one of "us," one of the victims of the crash:

Some of $u s$ are illegal, and some are not wanted,

Our work contract's out and we have to move on.

They chase us like outlaws, like rustlers, like thieves. (emphasis mine; lines 13-16)

Guthrie cannily shifts his narrator, exploring the consequences of namelessness: stopping to consider the conditions of being both "illegal" and "not wanted" (line 13). 


\section{Edward A. Shannon}

The shift from the "they" flown "back to the Mexican border" becomes not only the very broad "us" who are illegal or unwanted, not only the twenty-eight who died in that airplane, but more. Subject and speaker contract and expand simultaneously:

We died in your hills, we died in your deserts,

We died in your valleys and died on your plains.

We died 'neath your trees and we died in your bushes,

Both sides of the river, we died just the same. (lines 17-20)

Guthrie's compassion extends to so many in these lines-not just Braceros who died in the plane, or even those who died in the U.S.: "Both sides of the river, we died just the same." Here and elsewhere "the narrator is ... developed as someone who has suffered the same exploitation as the 'deportees"' (Kannan, "Memorializing 'Deportees'" 91). The simple recognition of - and dispensing with-borders humanizes all who live there; all human beings will someday "[die] just the same" (Guthrie, "Deportee," line 20). Moreover, the scene has shifted. In this song about farmworkers, Guthrie considers the unnamed dead who died away from the farms: in the "hills," and "deserts." The Bracero program specifically, and unfettered capitalism in general, are systems, Guthrie suggests, that do not respect borders. These systems kill workers in the U.S., and in Mexico; "[b]oth sides of the river, [they die] just the same" (line 20). The song's compassion embodies the voices of the dead in 1948, but also the dead of past generations. And, as it turns out, this long-lived, oft-performed song crosses another border: that between past and present, reaching to future generations.

Once Guthrie steps out of time to consider its broad expanse, he steps back in, and "Deportee" concludes, returning us to the specific 1948 tragedy:

The sky plane caught fire over Los Gatos Canyon, A fireball of lightning, and shook all our hills, Who are all these friends, all scattered like dry leaves?

The radio says, "They are just deportees." (lines 21-24)

Returning to this terrible moment, Guthrie moves again across that familiar linguistic border, when he writes that "a fireball of lightning . . . shook all our hills" (emphasis mine; line 22). These are not the United States' hills or Mexico's hills; they are North American hills: "our" hills. "We" were on that airplane as well as on the ground watching. Also 
familiar is his imagery of death, vegetation, and rot. The song begins with "peaches ... rott'ning, / [and] oranges piled in their creosote dumps" (lines 1-2) and ends with "friends . . . scattered like dry leaves" (line 23). Whether these friends are "illegal" or simply "not wanted," the injustice remains: "[the] radio says, 'They are just deportees'" (line 24).

In another grammatical and syntactic shift, a song of statements ends as a series of questions. The first question posed in the song occurs in sixth of seven stanzas with "Who are all these friends, all scattered like dry leaves?" The final stanza, then, is a litany of questions:

Is this the best way we can grow our big orchards?

Is this the best way we can grow our good fruit?

To fall like dry leaves to rot on my topsoil

And be called by no name except "deportees"? (lines 25-28)

Guthrie revisits the themes and strategies of his song, again using a childlike voice to ask, "Is this the best way we can grow our big orchards?" (line 25). He shifts from the "they" of the opening lines, emphatically choosing the "we" and "our" of these final lines to erase the distance between owner and worker; U.S. and Mexico; citizen and guest; named and unnamed; living and dead.

In 2013, California poet Tim Z. Hernandez asked the same question about the Bracero workers Guthrie had asked in "Reuben James": "What were their names, tell me, what were their names?" (Guthrie, "Reuben" line 7) and began to get answers: ${ }^{6}$

Hernandez dug through records at the Fresno County recorder's office and coverage of the crash from a local Spanish-language newspaper ... Hernandez filled in information and double-checked name spellings by talking with surviving family members. (Wollan)

\footnotetext{
${ }^{6}$ Out of respect to the project Guthrie began over seventy years ago, the list of twentyeight farm workers names finally recorded on the memorial should be listed here:

"Miguel Negroros Alvarez, Francisco Llamas Duram Santiago Garcia Elizondo, Rosalio Padilla Estrada, Tomasa Avena De Garcia, Bernabe Lopez Garcia, Salvador Sandoval Hernandez, Severo Medina Lara, Elias Trujillo Macias, Jose Rodriguez Macias, Tomas Padilla Marquez, Luis Lopez Medina, Manuel Calderon Merino, Luis Cuevas Miranda, Martin Razo Navarro, Ygnacio Perez Navarro, Roman Ochoa Ochoa, Ramon Ramirez Paredes, Apolonio Ramirez Placencia, Guadalupe Laura Ramirez, Alberto Carlos Raygoza, Guadalupe Hernandez Rodriguez, Maria Santana Rodriguez, Juan Valenzuela Ruiz, Wencealado Ruiz, Jose Valdivia Sanchez, Jesus Meza Santos [and], Baldomero Marcas Torres" (Orozco).
} 


\section{Edward A. Shannon}

Hernandez has since helped memorialize the dead by name both in 2017's All They Will Call You and at the site of the original "mass grave, [where previously] a diminutive stone read only: '28 Mexican Citizens Who Died In An Airplane Accident Near Coalinga California on Jan. 28, 1948 R.I.P."' (Wollan). He has also collaborated with roots blues band Lance Canales \& the Flood to record a version of the song that includes all the names ("Deportee's" [sic]).

Canales's 2012 cover version honors not only Guthrie's lyrics but also the long tradition of cover versions of "Deportee," adapting and expanding the song. Canales mostly dispenses with the ambiguity of "us," "them," "me," and "you." His opening lines read: "they're flying me back to the Mexican border" and "we won't have a name when we ride the big airplane" (emphasis mine; Canales). Now that the names are known and can be spoken, printed, sung, and engraved on a memorial, this adaptation suggests that the time for ambiguity is past. In fact, Canales' views of "past" and "present" deeply inform his song. He expressed his

need to ground it in the present reality of the marginalization of immigrants in the US . . . [T] hat the old version of the song suggested that the tragedy of the plane crash - and by extension, other immigration tragedies-were histories rather than present realities . . . like a "fable" that was no longer real. (Kannan, "Memorializing 'Deportees"' 87)

The song's unique ability to address and transgress all manner of borders appears again in the Lance Canales \& the Flood version. Canales had "troubled feelings over the older arrangements of 'Deportees,"' which tended to put "'Native peoples, Indigenous peoples . . . in the past tense"' (quoted in Kannan, "Memorializing 'Deportees'" 87). Reflecting on his own heritage, "the fact that he is half Mexican, half Native American" (Kannan, "Memorializing 'Deportees"' 87), Canales fords borders of time, nation, and ethnic identity addressing the lyric's tense.

Musically, Canales breaks the quiet early rumbling bars of his song with the stark twang of a guitar and a husky Springsteen-esque growl. Continuing his liberties with the lyrics, he sings, "some of us are illegal and most are unwanted" (emphasis mine; Canales). Folky strumming gives way to contemporary production values; between stanzas, Canales dubs in a hushed voice at a lower frequency, whispering all twenty-eight names. The slow parade of names, the twanging guitars, and locomotive beat produces one of the most stirring versions of Guthrie's "last great 
song" (Klein 362), now naming all twenty-eight "friends, [no longer] scattered like dry leaves" (line 23).

Setting the historical record straight on their account speaks to the legitimacy of Guthrie's complaint and the power of his song: names lost for sixty-five years - a lifetime - have been recovered; memorials have been erected, and Guthrie's question has been answered. Guthrie's work, of course, was all about using song to deliver news, address injustice, instruct the ignorant, advance political change, and encourage compassion for self and other. On Dec. 3, 1944, Guthrie opened his WNEW radio show with what has become an oft-quoted manifesto:

I hate a song that makes you think that you are just born to lose. Bound to lose. No good to nobody. No good for nothing . . . Songs that run you down or poke fun at you on account of your bad luck or hard traveling. I'm out to fight those songs to my very last breath of air and my last drop of blood ... And the songs that I sing are made up for the most part by all sorts of folks just about like you. (Guthrie, "WNEW" 223)

In that final line, Guthrie again plays fast and lose with his pronouns: "the songs that I sing are made up for the most part by . . f folks just . . . like you" (emphasis mine; Guthrie, "WNEW" 223). It was certainly true that Guthrie performed the songs of others, but if ever there was an artist capable of and known for writing his own material, it was Woody Guthrie. His attribution of his songs to his audience is an empowering act in the spirit of the linguistic border crossing of "Deportee." And to the extent that performers like Canales (and before him, Johnny Cash, Judy Collins, Bruce Springsteen, and others) have added to, amended, and revised "Deportee," Guthrie was speaking the truth, as he so often did.

Keeping alive the memory of twenty-eight lost workers, inspiring new generations to seek out their names and memorialize them as individuals: all of this endorses Guthrie's belief that no one is "born to lose" (Guthrie, "WNEW" 223), as pessimists might have assumed of "Jesus y María," and their "brothers and sisters ... working the fruit trees" (Guthrie, "Deportee" line 11). These workers had the worst kind of "bad luck [and] hard traveling" (Guthrie, "WNEW" 223), but, in this instance, anyway, Guthrie made good on his promise to "fight [defeatist] songs to [his] very last breath of air" (Guthrie, "WNEW" 223). In fact, "Deportee" kept fighting for more than half a century after that final breath.

Ironically, though, by naming the dead, Canales and Hernandez have again transformed those individuals into symbols of the many. Visiting 


\section{Edward A. Shannon}

the new memorial of the crash site or listening to Canales' recording, one cannot help but wonder: how many other deportees and workers remain unnamed, how many more "rode the truck till they took down and died" ("Deportee" line 12)? Guthrie would probably appreciate this latest posthumous collaboration, and that a once obscure lyric has become one of his most oft-covered songs, and that the song has had a direct impact on the legacy of those he wrote about, their families, and the workers and other travelers "[wading] that river" (Guthrie, "Deportee" line 9) and crossing those borders.

\section{WORKS CITED}

American Masters: Woody Guthrie. Dir. Peter Frumkin. DVD. PBS. 2007.

"A People at War: A Prelude to War" National Archives and Records Administration.https://www.archives.gov/exhibits/a people at war/pr elude to war/uss reuben_james.html. n.d. Accessed 27 Dec. 2019.

Blake, Matthew. "Woody Guthrie: A Dust Bowl Representative in the Communist Party Press." Journalism History, vol. 35, no. 4, 2010, pp. 184-193. https://doi.org/10.1080/00947679.2010.12062803

Chávez, Sergio "The Sonoran Desert's Domestic Bracero Programme: Institutional Actors and the Cretion of Labour Migration Streams." International Migration, vol. 50, no. 2, 2012, pp. 20-40. https://doi.org/10.1111/j.1468-2435.2009.00544.x

Cray, Ed. Ramblin' Man: The Life and Times of Woody Guthrie. Norton, 2004.

"DC3 Aircraft Crash Site in Los Gatos Canyon." Historical Research \& Preservation. Three Rocks Research. http://www.picacho.org/interest/dc3site.html. 23 Sept. 2007. Accessed 19 Aug. 2014.

Deportee's [sic]. Lancecanalesandtheflood.com n.d. Accessed 29 March 2014.

Editorial Board. "Donald Trump's Deportation Nation." New York Times. New York Times. Aug. 31, 2016. Accessed 2 Jan. 272020.

Guthrie, Woody. "Christ for President." Lyrics. WoodyGuthrie.org. 30 Dec. 2019. The Woody Guthrie Foundation. n.d. Accessed 29 Dec. 2019. . "Grand Coulee Dam." Lyrics. WoodyGuthrie.org. The Woody Guthrie Foundation. n.d. Accessed 30 Dec. 2019. . "I Just Want to Sing Your Name." Lyrics. WoodyGuthrie.org. The Woody Guthrie Foundation. n.d. Accessed 30 Dec. 2019. . "My Life." American Folksong. (1947) Oak Publications, 1961. pp. 1-8. 
. "Plane Wreck at Los Gatos (also known as "Deportee")." Lyrics. WoodyGuthrie.org. The Woody Guthrie Foundation. n.d. Accessed 30 Dec. 2019.

. "Plane Wreck At Los Gatos (Deportee) (Goodbye Juan)." Hard Travelin': Das Woody Guthrie Buch, Songtexte und Essays. Palmyra, 2002. pp. 44-46.

. "Pastures of Plenty." Lyrics. WoodyGuthrie.org. The Woody Guthrie Foundation. n.d. Accessed 30 Dec. 2019.

. "The Sinking of the Reuben James." Lyrics. WoodyGuthrie.org.

The Woody Guthrie Foundation. n.d. Accessed 30 Dec. 2019.

. "This Land is Your Land." Lyrics. WoodyGuthrie.org. The

Woody Guthrie Foundation. n.d. Accessed 30 Dec. 2019.

. "WNEW." Born To Win. Ed. Robert Shelton. Macmillan, 1965.

pp. $220-227$.

Hernandez, Tim Z. All They Will Call You. U of Arizona P. 2018. "Plane Wreck at Los Gatos." Current Projects.

TimZHernandez.com. n.d. Accessed 29 March 2014.

Isenberg, Nancy. White Trash: The 400-Year Untold History of Class in America. Penguin Books, 2017. https://doi.org/10.1057/s41286-016$\underline{0019-1}$

Jackson, Mark Allan. Prophet Singer: The Voice and Vision of Woody Guthrie. UP of Mississippi, 2007.

Kannan, Vani. "Memorializing 'Deportees': Conversations with Tim Hernandez and Lance Canales." Woody Guthrie Annual 1, 2015, pp. 83-100.

. "Rhetorics of Song: Critique, Persuasion \& Education In Woody Guthrie \& Martin Hoffman's 'Deportees."' Master's thesis, Department of English Colorado State University Fort Collins, Colorado 2014.

Kanstroom, Dan. Deportation Nation: Outsiders in American History. Harvard UP, 2007.

Kaufman, Will. Woody Guthrie: American Radical. U of Illinois P, 2011. Klein, Joe. Woody Guthrie: A Life. Ballantine Books, 1980.

Kreiser, Christine M. "They Are Just Deportees." American History. Oct. 2006. pp. 30.

Marcum, Diana. "Names Emerge from Shadows of 1948 Crash." Los Angeles Times. 9 July 2013. Accessed 21 Aug. 2014.

Masquelier, Adeline. "Why Katrina's Victims Aren't Refugees: Musings on a 'Dirty' Word." American Anthropologist, vol. 108, no. 4, 2006, pp. 735-743. https://doi.org/10.1525/aa.2006.108.4.735 
Overmyer-Velázquez, Mark. "Good Neighbors and White Mexicans: Constructing Race and Nation on the Mexico-U.S. Border." Journal of American Ethnic History, vol. 33, no. 1, 2013, pp. 5-34. https://doi.org/10.5406/jamerethnhist.33.1.0005

Orozco, Ron. "Fresno Memorial Unveiled with 'Deportee' Names from 1948 Crash." The Fresno Bee. 22 Dec. 2013. Accessed 2 September 2013.

"32 Killed in Crash of Charter Plane." New York Times. New York Times. 29 Jan. 1948. Accessed 29 Dec. 272019.

Wollan, Malia. "65 Years Later, a Memorial Gives Names to Crash Victims." New York Times. New York Times. 3 Sept. 2013. Accessed 29 Dec. 272019. 